\title{
Organosomatic Index and Behavioural Responses of Clarias Gariepinus to Dichlorvos.
}

\author{
E.N. Ogamba*; E.I. Seiyaboh and A.H. Gijo \\ Department of Biological Sciences, Niger Delta University, Wilberforce Island, Bayelsa State, Nigeria.
}

\begin{abstract}
This study assessed the effect of Dichlorvos on the organosomatic index (hepatosmatic, cardiosmatic, renatosomatic and splenosomatic indices) and behavioural responses of Clarias gariepinus. Thirty five healthy juvenile Clarias gariepinus species. (mean weight $57.92+1.85 \mathrm{~g}$; mean length $24.17+0.17 \mathrm{~cm}$ ) were exposed to sublethal concentrations of dichlorvos $(0.30,0.40,0.5 .50$ and $0.60 \mathrm{ppm})$. The fluctuations in the organosomatic indices were not significant $(p>0.05)$. However, all the indices recorded their highest values at the highest concentration of dichlorvos $(0.60 \mathrm{PPm})$. Obvious abnormal behavioral responses such as restlessness, quick circular movements, rolling on the back, excessive mucus productions on the body surface were observed among the exposed fish. This study showed that sub lethal concentrations of dichorvos had adverse effects on Clarias gariepinus. Thus, dichlorvos should be used with caution in agricultural field applications likely to introduce acute levels of the toxicant into the environment.
\end{abstract}

Key words: Organosomatic index, Behavioural responses, Dichlorvos, Clarias gariepinus, Nigeria.

\section{Introduction}

Pesticides are poisons meant to kill unwanted living organisms. They include herbicides, insecticides, fungicides and more. It is known that only a small fraction of pesticides get to the target pest when applied, leaving the greater percentage as an unintended pollutant in the environment, including in soil, air and water, or on nearby vegetables. This is because pesticides can move from the site of application via drift, volatilization, leaching and runoff.

Pesticides have been used for over five decades in Nigeria, but their effect on the Nigerian environment is not taken into consideration and therefore, adequate measures are not taken to effectively manage the use of pesticides in the country. Gill et al. (1990) reported the presence of organochlorine compounds in fish organs, which thus indicate that pesticides may be persistent in water and bioaccumulation in tissues of aquatic organisms. The toxicity of insecticides vary depending on the type of insecticide and the animal species involved (Vasuathi et al.,1989).

Dichlorvos or 2,2-dichlorovinyl dimethyl 1, phosphate (DDVP) is a highly volatile organophosphate pesticide widely used as a fumigant to control household pest, in public health, and protecting stored products from insects. Dichlorvos is used to treat a variety of parasite worm infections in dogs; livestock and humans. It acts against insects as both a contact and a stomach poison. According to the United States Environmental Protection Agency (USEPA, 1991), Studies show that Herbicides contain an active ingredient which is highly toxic to both cold and warm water fishes and shown in a series of tests to cause vertebral deformities in fishes. Glyphosate or glysophate containing products can cause sub lethal effects such as erratic swimming and bad breathing which increase the fish's chances of being eaten by predators (Moore and Wasing,2001). Herbicides were also found to inhibit the growth of two common cyanobacteria, at all levels of application and disrupt the nitrogen fixation processes (Ajani et al, 2007)

The genus clarias are unique in their ability to survive a wide range of environmental extremes (Akiri, 1987). They have a highly efficient air breathing organ, which allows them to survive in oxygen depleted water (Jordan, 1978), migrate for long distances as long as $1.2 \mathrm{~km}$ (Covertenary and Bruton, 1979). They have proved a serious threat to native populations in areas where they have been introduced because of their superior adaptability (Covertenary and Bruton, 1979). Clarias gariepinus has fast growth rate in the natural and cultural environment and has proved to be successful aquaculture species (Reed and Bardach, 1979). Clarias species are able to survive salinity increase of up to $25 \%$ (Chervinsky, 1982). Clarias gariepinus is in high demand in Nigeria due to its food value.

There is an increasing awareness that herbicides contamination of water could have devastating effect on aquatic plants (Ambrosi, et al 1978), and the ability to interfere with the organosomatic indices and behavioral patterns of fish. It is difficult to assess the level of toxicity of pesticides on organisms in the aquatic environment because of the complex nature of aquatic ecosystem. Thus, toxicological methods have been perceived as an adequate evaluation of the effect on aquatic populations (Petrocelli, 1985). 
The government and private individuals in the country are expanding the present agricultural base of the economy. This will entail increased use of various pesticides to control weeds and insect pests on cash and food crops with the attendant contamination of water bodies through runoffs and drifts (Avoja and Oti, 1997). This underscores the need for this study to investigate and examine the organosomatic changes and behavioral responses of Clarias gariepinus exposed to Dichlorvos.

\section{Experimental Procedures}

\section{Materials And Methods}

Thirty- five healthy juvenile African catfish Clarias gariepinus (mean weight $0.10 \pm 0.00 \mathrm{~g}$; mean, length, 24:17 $\pm 0.17 \mathrm{~cm}$ ), were obtained from a private fish farm at aquaculture Research centre Aluu, Choba, PortHarcourt, Rivers State. They were transported in 19 liters cold plastic container covered with net by car to the laboratory in the Department of Biological Sciences Niger Delta University, Wilberforce Island, Bayelsa State. On arrival, the fish were acclimated individually in circular aquaria for seven days (7 days).

The top of the aquaria were covered with fishing net to control escape of the fish. The fishing net had a slit at the middle for cleaning the aquaria. In the laboratory, the water from the private fish farm was gradually replaced with bore-hole water and the aquarium was washed with a piece of foam at 10-11 hours daily. The natural day and night photo period were maintained. During this period, the fish were fed with pelleted feeds containing $35 \%$ crude protein once per day.

A range finding test was carried out using the toxicant Dichlorvos. Five concentrations of Dichlorvos (Obtained from Diazenhoff Nigeria Limited Port Harcourt) were prepared from the original solution $(500 \mathrm{~g} / \mathrm{l})$. The five concentrations $(0.00,0.30,040,0.50$ and $0.60 \mathrm{ppm})$ used were prepared using the methods described by Grinshaw (1978). The test solution was renewed daily immediately after washing and the fishes were fed once daily as in the acclimation period of seven days.

The purpose of the trial test was to determine the range of concentration to be used for the definitive test.

Sub-lethal concentrations for the definitive test were done based on the range finding test. The concentrations were the same as in the trial test. The test solution was renewed daily after washing the aquaria. Three fishes were exposed to each concentration of Dichlorvos for 96 hours. The water was filled to 25 liters point before the introduction of the toxicant; after which the water was made up to the 30 liters mark.

At the end of the experiment, the fishes were then killed by a blow on the head and the organs (heart, kidney, liver and spleen ) removed and weighed for organ indices assessment.

The organ indices were calculated according to the methods of Jenkins (2004). Data obtained were subjected to statistical analysis using one way analysis of variance at $95 \%$ probability and means separated by Duncan's multiple range test at 95\% probability (Wahua, 1999) .

\section{Physicochemical Parameters Of Aquaria Water.}

The following physicochemical parameters; temperature, conductivity, $\mathrm{pH}$, salinity, Dissolved Oxygen (DO), alkalinity and turbidity, were measured on weekly basis according to the standard methods described in the guidelines of APHA, (1998)

\section{Physicochemical Properties Of The Exposed Aquaria.}

\section{Results}

Results of the physico-chemical properties of the exposed aquaria are presented in Table 1. Most of the Values were comparable to those of the control with no clear relationship displayed between the parameters and the concentration of Dichlorvos. However, conductivity and alkalinity appeared to increase slightly with increased concentration of Dichlorvos, while Dissolved Oxygen appeared slightly depressed (Table 1.)Nevertheless, the variations were not statistically significant $(P>0.05)$.

Table 1. physicochemical properties of the exposed Aquaria.

\begin{tabular}{|l|l|l|l|l|l|l|}
\hline $\begin{array}{l}\text { Concentration } \\
\text { of Dichlorvos } \\
(\mathrm{PPM})\end{array}$ & $\mathrm{PH}$ & Conductivity & Temperature & Turbidity & $\begin{array}{c}\text { Dissoloved } \\
\text { Oxygen }\end{array}$ & \begin{tabular}{l} 
Alkalinity \\
\hline 0.00
\end{tabular} \\
\hline 0.30 & $6.27 \pm 0.08^{\mathrm{a}}$ & $99.50 \pm 21.46^{\mathrm{a}}$ & $26.00 \pm 0.00^{\mathrm{a}}$ & $0.25 \pm 0.45^{\mathrm{a}}$ & $7.21 \pm 0.02^{\mathrm{a}}$ & $12.33 \pm 0.78^{\mathrm{a}}$ \\
\hline 0.40 & $6.37 \pm 0.07^{\mathrm{a}}$ & $105.80 \pm 18.00^{\mathrm{a}}$ & $26.10 \pm 0.32^{\mathrm{a}}$ & $0.20 \pm 0.45^{\mathrm{a}}$ & $6.28 \pm 0.5^{\mathrm{a}}$ & $12.40 \pm 0.09^{\mathrm{a}}$ \\
\hline 0.50 & $6.37 \pm 0.07^{\mathrm{a}}$ & $108.75 \pm 20.70^{\mathrm{a}}$ & $26.00 \pm 0.00^{\mathrm{a}}$ & $0.50 \pm 0.57^{\mathrm{a}}$ & $6.61 \pm 0.05^{\mathrm{a}}$ & $15.25 \pm 0.96^{\mathrm{a}}$ \\
\hline 0.60 & $6.35 \pm 0.11^{\mathrm{a}}$ & $130.12 \pm 14.04^{\mathrm{a}}$ & $26.13 \pm 0.35^{\mathrm{a}}$ & $0.50 \pm 0.58^{\mathrm{a}}$ & $6.17 \pm 0.01^{\mathrm{a}}$ & $14.88 \pm 0.99^{\mathrm{a}}$ \\
\hline
\end{tabular}




\section{Organosomatic Indices.}

The results of the organosomatic indices of Clarias gariepinus exposed to the various concentrations of dichlorvos are presented in Table 2. The variations in the organosomatic indices of the exposed fish were minimal. However, there were fluctuations in the values that appeared to vary with the concentration of the toxicant. All the organ indices; Hepatosomatic index (HSI). Cardiosomatic index (CSI). Renatosomatic index (RSI), and splenosomatic index (SSI), had their highest values at the highest concentration $(0.60 \mathrm{ppm})$ of Dichlorvos, Table 2.

Table 2: Organosomatic indices of Clarias gariepinus exposed to Dichlorvos.

\begin{tabular}{|l|l|l|l|l|l|l|}
\hline $\begin{array}{l}\text { Concentratio } \\
\mathrm{n} \\
\text { of } \\
\begin{array}{l}\text { Dichlorvos } \\
(\mathrm{PPM})\end{array}\end{array}$ & $\begin{array}{l}\text { Initial } \\
\text { condition } \\
(\mathrm{K})\end{array}$ & $\begin{array}{l}\text { Final } \\
\text { condition }(\mathrm{k} 2\end{array}$ & $\begin{array}{l}\text { Hepatosomati } \\
\mathrm{c} \text { Index }\end{array}$ & $\begin{array}{l}\text { Cardiosomatic } \\
\text { Index (Heart) }\end{array}$ & $\begin{array}{l}\text { Renatosomatic } \\
\text { Index (Kidney) }\end{array}$ & $\begin{array}{l}\text { Spleenosomatic } \\
\text { Index (Spleen) }\end{array}$ \\
\hline 0.00 & $0.54 \pm 0.2^{\mathrm{a}}$ & $0.57 \pm 0.10^{\mathrm{a}}$ & $1.17 \pm 0.08^{\mathrm{a}}$ & $0.24 \pm 0.02^{\mathrm{a}}$ & $0.39 \pm 0.01^{\mathrm{a}}$ & $0.22 \pm 0.01^{\mathrm{ab}}$ \\
\hline 0.30 & $0.56 \pm 0.25^{\mathrm{a}}$ & $0.57 \pm 0.20^{\mathrm{a}}$ & $0.83 \pm 0.9^{\mathrm{ab}}$ & $0.19 \pm 0.09^{\mathrm{ab}}$ & $0.31 \pm 0.43^{\mathrm{ab}}$ & $0.22 \pm 0.01^{\mathrm{ab}}$ \\
\hline 0.40 & $0.58 \pm 0.30^{\mathrm{a}}$ & $0.56 \pm 0.20^{\mathrm{a}}$ & $0.92 \pm 0.05^{\mathrm{ab}}$ & $0.20 \pm 0.01^{\mathrm{ab}}$ & $0.43 \pm 0.02^{\mathrm{a}}$ & $0.18 \pm 0.03^{\mathrm{ab}}$ \\
\hline 0.50 & $0.54 \pm 0.00^{\mathrm{a}}$ & $0.53 \pm 0.10^{\mathrm{a}}$ & $0.76 \pm 0.13^{\mathrm{ab}}$ & $0.18 \pm 0.02^{\mathrm{ab}}$ & $0.38 \pm 0.01^{\mathrm{a}}$ & $0.24 \pm 0.01^{\mathrm{ab}}$ \\
\hline 0.60 & $0.50 \pm 0.00^{\mathrm{a}}$ & $0.51 \pm 0.21^{\mathrm{a}}$ & $1.40 \pm 0.19^{\mathrm{a}}$ & $0.25 \pm 0.02^{\mathrm{a}}$ & $0.47 \pm 0.04^{\mathrm{a}}$ & $0.30 \pm 0.00^{\mathrm{a}}$ \\
\hline
\end{tabular}

\section{Behavioral Changes}

Behavioral changes were least obvious in the experimental fish exposed to the lowest concentration $(0.30 \mathrm{ppm})$ of Dichlorvos. The rest doses caused observable changes in the behavioral patterns of the exposed Clarias gariepinus species. The behavioural changes included restlessness,

Difficulty in movement co-ordination and postural orientation before death in some of the exposed fish. Intermittently the fish turned on the flank and swam in half circles. Also, sudden quick movements, settling at the bottom and excessive mucus secretion on the skin were observed.

\section{Discussion}

The variations in the mean values of the water quality parameters were minimal throughout the period of study. Dissolved oxygen was observed to decrease with increase in the concentration of dichlovos. This was not surprising as Oxygen had been reported to be depressed in polluted and contaminated water bodies (Ogamba et al; 2005). Nevertheless, all the values of the water quality parameter were within the suggested tolerance range of warm water species (Adeniyi et al; 1989). The parameters therefore, could not have caused the abnormal behavioural changes exhibited by the Clarias gariepinus species exposed to dichlorvos.

The condition factor values of the experimental fish appeared to increase at lower concentrations of dichlorvos. It could be that at lower concentrations, the toxicant may have triggered some biochemical responses in the fish such as increased metabolism, blood production and water intake as a coping mechanism which may have induced an apparent improvement in the condition of the fish. However, at higher concentrations of dichlorvos, the condition factor of the fish decreased. This may be due to the observed increase in agitated movement and restlessness, reduction in feeding activity, possible loss of ions due to the increased activity, leading to possible loss of body fluid. The reduction in condition factor if persistent could lead to reduction in growth rate and reproductive capacity (Jenkins, 2004, Gabriel et al; 2009). The hepatosomatic index was highest at the highest concentration of dichlorvos. The liver as the center of enzymatic decontamination will expectedly activate various metabolic processes, such as increased protein synthesis and lipid storage which frequently occurred in fish exposed to organochloride compounds, to cope with the toxicant (Anderson et al; 1988). The values of the cardiosomatic index fluctuated minimally, suggesting minimal impact on the heart by the toxicant. However, the highest CSI recorded at the highest concentration of dichlorvos could be as a result of the combined effect of increased heart rate expected under stress conditions, possible loss of ions from the heart tissues and pericardial fluid, and subsequent absorption of water due to impaired osmoregulatory ability. The renatosomatic index and Splenosomatic index were also elevated in the experimental fish. In fish, these organs are involved in blood production, blood filtration and immune response processes. Jenkins (2004) reported that increase in RSI and SSI may be a mechanism to cope with the effect of toxicants by increasing their hemolytic capacity.

The experimental fish in the exposed aquaria showed restlessness, sudden quick movements, rolling movements and swimming on the back at high doses. These abnormal behavioural responses in fish exposed to dichlorvos were similar to those reported earlier in fishes (Cyprinis carpio, Heterobranchus bidorsalis and Clarias gariepinus) exposed to various toxicants (Avojah and Oti, 2002; Luskova et al; 2002; Ogamba et al; 2011). The stress related behavioural responses of the fish suggest that they suffered respiratory impairment and general disruption of metabolic processes. The observed accumulation of mucus on the body surfaces of the fish was a clear indication of the poisoning effects of dichlorvos on organs, glands and tissues similar to those 
reported for fish exposed to various toxicants (Das and Mukherjee, 2003; Ajani et al; 2007; Okechukwu and Auta, 2007).

The sub lethal concentrations of Dichlorvos used in this study produced measurable and significant changes in the condition factor, hepatosomatic, cardiosomatic, renatosmatic, splenosomatic indices, and abnormal behavioural changes in Clarias gariepinus. Therefore, Dichlorvos should be used with caution in Agricultural field applications which may lead to acute exposure of terrestrial and aquatic organisms thereby destabilizing the natural ecosystem. The residual effects of dichlorvos in different body tissues of fish and other animals should be evaluated as man is the ultimate recipient.

\section{Acknowledgement}

We are grateful to the staff of Federal Medical Centre Laboratories Yenagoa and Niger Delta University Post-graduate Laboratories for assisting with the analysis.

\section{References}

[1]. Adeniyi, S.W.,Boyd, W.F. and Orie, K.A.(19789). Analysis of water quality parameters of tolerance ranges of warm water fish species. Vol.7: PP $103-110$.

[2]. Ajani, F., Olakunle, O.A., Agbede, S.A. (2007). Hormonal and haematolgical responses of Clarias gariepinus (Burchell 1822) to nitrite toxicity. J. fish int. 2 (1): $48-53$.

[3]. Akiri, J.A. (1987). Adaptation of aquatic animals to extreme conditions. Environmental perspectives Vol.8.PP.240-243.

[4]. Anderson, T., Forlin, L., Hardig, J., Larson A. (1988). Physiological Disturbances in fish living in coastal water polluted with bleached Kraft mill effluents. Can. J. fish Aquat. Sci. 45: 1525 - 1536

[5]. Americam Public Health Association (APHA), (1998). Standard methods for the evaluation of water and waste water. 20 ${ }^{\text {th }}$ edition Washington, D.C PP.265-274

[6]. Avoaja, D.A. and Oti, E.E. (1997). Effect of sublethal concentrations of some pesticides on the growth and survival of the fingerlings of the African catfish heteroclarias (hybrid)_. Nigeria J. Biotech. PP: $40-45$.

[7]. Ambrosi, D.,A. Isenee and J. Macchia (1978). Distribution of oxidiazon And phoslone in an aquatic model. American Chemical Society $26(1): 50=-53$.

[8]. Chervinski, B.R. (1982). Adaptation of fishes to increased saline concentration in freshwater environment. Limnol. Oceanogr., 12: $310-330$

[9]. Convertenary, K.A. and Bruton, I.E. (1979). Superiority of Clarias gariepinus compared to aquatic fauna. Fish soc., 4:232 - 246.

[10]. Das, B.K. and Mukherjee, M.D. (2003). Toxicity of cypermethrin in Labeorolito fingerlings: biochemical, enzymatic and hematological consequences. Comp. biochemist. C. toxicol. Pharmacolo. 134: 109-121.

[11]. Gabriel, U.U., Obomanu, F.G. and Edori, O.S. (2009). Haematology, plasma enzymes and organ indices of Clarias gariepinus after intramuscular injection with aqueous leaves extracts of Lepidagathis alopecuroides. Afri. Jour. of Biochem. Research, Vol.3(9). PP $312-316$.

[12]. Gill, T.S., Tewari, H., Pande, J. (1990). Sublethal effects of an organophosphorus insecticide on certain metabolic levels in a freshwater fish, Puntuis conchonius Hamilton. Pest. Biochem. Physiol. 36: 290 - 299.

[13]. Grishaw, G. (1978). Chemistry. Ibadan. Evans brothers Ltd. PP32

[14]. Jackson, P.B.N (1988). Aquaculture in Africa, PP.459-480.

[15]. Jenkins, J.A. (2004). Fish bioindicators of ecosystem condition at the Calcasieu estuay, Louisiana. National wetlands Rresearch Centre, USGS, Lafayette P.54.

[16]. Jordan, O.N.(1976). Respiratory organs and functions in certain aquatic models aquaculture resources. Vol.16:PP 360 - 32 .

[17]. Moore,A and Wasing, C.P. (2001). Sublethal effects of the pesticide diazinon on olfactory function in mature male Atlantic salmon Parr. J. fish Bio.48: 758 - 775.

[18]. Luskova, V., Svoboda, M. Kolarova., J. (2002). The effects of diazinon on blood plasma biochemistry in carp (Cyprinus carppio). ACT. VET. BRNO 71: 117 -125.

[19]. Ogamba, E.N., I.K.E.Ekweozor and E.R. Daka (2005). The influence of human activities on the zooplankton of Elechi Creeck Complex in the Niger Delta. Africa J. Environment Pollut. Health, 4 ()2): $31-38$

[20]. Okechukwu, E.O., and Auta, J. (2007). The effects of sublethal doses of lambda - cyhalothrin on some biochemical characteristics of the African catfish, Clarias gariepinus. Petrocelli, A.D. (1985). Fundamental of aquatic toxicology methods and applications. Vol.12PP: 325 - 376.

[21]. United States Environmental protection Agecy (USEPA) (1991).

[22]. Dichlorvos. Revocation of tolerance and food additive regulation fed. Regist. $-456: 5788-89$.

[23]. Vasuathi, R.P. Baskaran, S. palanchymy and F.D. Arun (1989). impact of carbonfuran on feeding energetics in some freshwater fishes. Envrionment Ecol.,8: 40 - 45.

[24]. Wahua, T.A.T (1999). Applied statistics for scientific studies. Africa link books, Aba Nigeria, 365P 